\title{
LARVICIDAL EFFICACY OF SIX INSECTICIDES AGAINST CULEX QUINQUEFASCIATUS SAY (DIPTERA: CULICIDAE) LARVAE
}

\author{
MUNIRA NASIRUDDIN ${ }^{1}$ AND SHAHEDA YASMIN BHUIYAN \\ ${ }^{1}$ Department of Zoology, University of Chittagong, Chittagong 4331, Bangladesh
}

\begin{abstract}
Searching for potent larvicidal toxic effects of six synthetic organophosphate insecticides (Diazinon 60 EC, Solar 55 EC, Malathion 57 EC, Delathroit 40 EC, Parathrin 10 EC and Clorasid 20 EC) were evaluated in the laboratory against $3^{\text {rd }}$ or $4^{\text {th }}$ instar larvae of the mosquito species, Culex quinquefasciatus Say. The tested insecticides: Diazinon (Dizinol) 60 EC, Solar (Chloropyrics 50\% + Cypermethrin 5\%) 55 EC, Malathion (Sithion) 57 EC, Delathroit (Dimehoate) 40 EC, Parathrin (Cypermethrin) 10 EC and Clorasid (Chloropyrics) 20 EC showed $\mathrm{LC}_{50}$ values at application dosages 0.00250-0.05 ppm, 0.0001-0.0025 ppm, 0.00025-0.005 ppm, 0.0005-0.001 ppm, 0.0001-0.002 ppm and $0.00025-0.0025 \mathrm{ppm}$ to be $8.609 \times 10^{-3} \mathrm{ppm}, 4.440 \times 10^{-4} \mathrm{ppm}, 9.094 \times 10^{-4} \mathrm{ppm}, 24.215 \times 10^{-}$ ${ }^{5} \mathrm{ppm}, 4.797 \times 10^{-4} \mathrm{ppm}$ and $7.022 \times 10^{-4} \mathrm{ppm}$ respectively. Among the six insecticides, on the basis of $\mathrm{LC}_{50}$ and relative potency values, Delathroit $40 \mathrm{EC}$ was the most toxic followed by Solar 40 EC > Parathrin 10 EC > Clorasid 20 EC > Malathion 57 EC > Diazinon 60 EC.
\end{abstract}

Key words: $\quad$ Larvicidal efficacy, Organophosphate insecticides, Toxicity, LC $_{50}$, Culex quinquefasciatus larva

\section{Introduction}

Mosquito control is necessary to prevent the transmission of mosquito-borne diseases and to protect people and livestock from their biting nuisance. But mosquito control is one of the major problems of the world in view of its ecology and vector behaviour. Effective mosquito control is often a complex and complicated task. The current mosquito control approach is based on synthetic insecticides. Insecticides especially organophosphorus and chlorinated hydrocarbons are extensively used as a control measure against the mosquitoes either as larvicides or as adulticides. The control of mosquito at the larval stage is necessary and efficient in integrated mosquito management. During the immature stage, mosquitoes are relatively less mobile, remaining more concentrated.

Several insecticides were tested in past against larvae of Culex quinquefascatus, $C$. fatigans, C. pipiens, Aedes aegypti, Anopheles culifacies, An. stephensi, An. fluviatilis and An. gambiae (Diptera : Culicdae) by Das et al. (1982), Verma and Rajvanshi (1983), Thavaselavam et al. (1993), Miyagi et al. (1994), Kalyanasundaran et al. (2003), Bansal and Singh (2006), Michaelakis and Koliopoules (2007), Kumar et al. (2010, 2011), Sarar et al. (2011) and Nkya et al. (2014) and at home by Begum and Mirdha (1975), Begum and Bhuiya (1983), Hossain et al. (1995), Shahjahan (1996), Ali et al. (1999), Zannat (2003) and Saha (2003). 
The present study was undertaken to test the potency of some commercial insecticides i.e. Dizinon (Dizinol) 60 EC, Solar (Chlorpyrics 50\% + Cypermethrin 5\%) 55 EC, Malathion (Sithion) 57 EC, Delathroit (Dimethoate) 40 EC, Parathrin (Cypermethrin) 10 EC and Clorasid (Chloropyrics) 20 EC. In this investigation, toxic effects of the six synthetic organophosphorus insecticides were examined for their toxicity against the mosquito larvae Culex quinquefasciatus Say.

\section{Materials and Methods}

To study the toxic effect of six insecticides: Diazinon Dizinol) 60 EC, Solar (Chloropyrics 50\% + Cypermethrin 5\%) 55 EC, Malathion (Sithion) 57 EC, Delathroit (Dimethoate) 40 EC, Parathrin (Cypermethrin) 10 EC and Clorasid (Chloropyrics) 20 EC systematic short term bioassays were done in the Entomological research laboratory of Department of Zoology, Chittagong University. All the six insecticides were bought from the government-approved shop of Chittagong city. Larvae of the mosquito were collected by small hand sieve from drains and small stagnant water bodies of Chittagong University campus and reared in the laboratory in an aquarium containing stagnant water. The third or fourth instar larvae of Culex quinquefasciatus were sorted as experimental specimens. The experiments were conducted at $30 \pm 2{ }^{\circ} \mathrm{C}$ room temperature.

Before the final experiments, several preliminary screenings on different concentrations (ppm) of the insecticides were done. These preliminary experiments helped to ascertain the dose ranges for obtaining 1-99\% mortality. The bioassays were run in a series of glass beakers each containing $500 \mathrm{ml}$ of required concentration of the insecticide and run for a period of 24 hours. The different insecticide extracts in different doses were added to the beakers to determine the $\mathrm{LC}_{50}$ and $\mathrm{LC}_{90}$ values for $C$. quinquefasciatus larvae. Five concentrations of each extract were used in the final experiments. Ten $C$. quinquefasciatus larvae of third or fourth instars were released in each beaker and kept for 24 hours. Three replicates were done for each concentration. In each experiment a control was maintained in which the same number of mosquito larvae were released in same volume of tap water and was replicated in the same way. No food was supplied to the insects during the test period. All the beakers were netted on top.

Statistical analysis was done for the obtained data of the experiment. The dose concentrations were transferred to logarithms. Probit analysis was used to determine the $\mathrm{LC}_{50}$ and $\mathrm{LC}_{90}$ values of each insecticide. Values of $\mathrm{LC}_{50}$ and $\mathrm{LC}_{90}$ with $95 \%$ confidence intervals were analyzed in a computer based probit analysis programme. The regression equation was calculated from empirical probit, working probit, weighting probit, the values of which were taken from the tables given by Finney (1971). Expected probit was calculated from respective empirical probit. Values of chi square at 0.05 level and ANOVA- test at 0.01 and 0.05 level were calculated following Fisher and Yates (1963). The relative potency values were calculated by taking the highest $\mathrm{LC}_{50}$ value as unit. 


\section{Results and Discussion}

Effects of the insecticides on Culex quinquefasciatus larvae: The effectiveness of Diazinon (Dizinol) 60 EC, Solar (Chloropyrics 50\% + Cypermethrin 5\%) 55 EC, Malathion

Table 1. Toxicities of the six experimental insecticides on Culex quinquefasciatus larvae exposed for 24 hours.

\begin{tabular}{|c|c|c|c|c|c|c|}
\hline $\begin{array}{l}\text { Solvents } \\
\text { Toxicity } \\
\text { Parameters }\end{array}$ & $\begin{array}{l}\text { Diazinon } \\
60 \mathrm{EC}\end{array}$ & $\begin{array}{l}\text { Solar } \\
55 \mathrm{EC}\end{array}$ & $\begin{array}{l}\text { Malathion } \\
57 \text { EC }\end{array}$ & $\begin{array}{l}\text { Delathroit } \\
40 \text { EC }\end{array}$ & $\begin{array}{l}\text { Parathrin } \\
10 \text { EC }\end{array}$ & $\begin{array}{c}\text { Clorasid } 20 \\
\text { EC }\end{array}$ \\
\hline Dose range (ppm) & $0.0025-0.05$ & $0.0001-0.0025$ & $\begin{array}{c}0.00025- \\
0.005\end{array}$ & $\begin{array}{c}0.00005- \\
0.001\end{array}$ & $\begin{array}{l}0.0001- \\
0.002\end{array}$ & $\begin{array}{c}0.00025- \\
0.0025\end{array}$ \\
\hline $\begin{array}{l}\text { Mortality range } \\
\text { (\%) }\end{array}$ & $13.33-96.67$ & $10.00-96.67$ & $13.33-93.33$ & $10.00-93.33$ & $13.33-93.33$ & 13.33-96.67 \\
\hline Slope line values & $0.76 x+4.31$ & $2.21 x+3.60$ & $1.79 x+3.27$ & $1.29 x+2.98$ & $1.94 x+3.68$ & $2.94 x+2.51$ \\
\hline Chi-square value & 55.07 & 4.40 & 3.16 & 28.84 & 9.48 & 2.87 \\
\hline $\begin{array}{l}\text { Degrees of } \\
\text { freedom }\left(\chi^{2}\right)\end{array}$ & 4 & 4 & 4 & 4 & 4 & 4 \\
\hline P-value $\left(\chi^{<}\right)$ & $\mathrm{P}<0.05$ & $\mathrm{P}>0.05$ & $\mathrm{P}>0.05$ & $\mathrm{P}<0.05$ & $\mathrm{P}>0.05$ & $\mathrm{P}>0.05$ \\
\hline $\begin{array}{l}\text { ANOVA- value } \\
\text { (Treatment) }\end{array}$ & 213.99 & 62.89 & 448.28 & 120.98 & 134.30 & 46.00 \\
\hline $\begin{array}{l}\text { Degrees of } \\
\text { freedom } \\
\text { (ANOVA- test) } \\
\text { (Treatment) } \\
\end{array}$ & $\begin{array}{l}\mathrm{F}_{1}=4 \\
\mathrm{~F}_{2}=8\end{array}$ & $\begin{array}{l}\mathrm{F}_{1}=4 \\
\mathrm{~F}_{2}=8\end{array}$ & $\begin{array}{l}\mathrm{F}_{1}=4 \\
\mathrm{~F}_{2}=8\end{array}$ & $\begin{array}{l}\mathrm{F}_{1}=4 \\
\mathrm{~F}_{2}=8\end{array}$ & $\begin{array}{l}\mathrm{F}_{1}=4 \\
\mathrm{~F}_{2}=8\end{array}$ & $\begin{array}{l}\mathrm{F}_{1}=4 \\
\mathrm{~F}_{2}=8\end{array}$ \\
\hline $\begin{array}{l}\text { P-value } \\
\text { (Treatment) }\end{array}$ & $\begin{array}{c}\mathrm{P}<0.01<0.0 \\
5\end{array}$ & $\mathrm{P}<0.01<0.05$ & $\mathrm{P}<0.01<0.05$ & $\mathrm{P}<0.01<0.05$ & $\begin{array}{c}\mathrm{P}<0.01<0.0 \\
5\end{array}$ & $\mathrm{P}<0.01<0.05$ \\
\hline $\begin{array}{l}\text { ANOVA- value } \\
\text { (Replication) }\end{array}$ & 7.11 & 0.44 & 20.99 & 0.99 & 6.00 & 0.390 \\
\hline $\begin{array}{l}\text { Degrees of freedon } \\
\text { (ANOVA- test) } \\
\text { (Replication) } \\
\end{array}$ & $\begin{array}{l}\mathrm{F}_{1}=4 \\
\mathrm{~F}_{2}=8\end{array}$ & $\begin{array}{l}\mathrm{F}_{1}=4 \\
\mathrm{~F}_{2}=8\end{array}$ & $\begin{array}{l}\mathrm{F}_{1}=4 \\
\mathrm{~F}_{2}=8\end{array}$ & $\begin{array}{l}\mathrm{F}_{1}=4 \\
\mathrm{~F}_{2}=8\end{array}$ & $\begin{array}{l}\mathrm{F}_{1}=4 \\
\mathrm{~F}_{2}=8\end{array}$ & $\begin{array}{l}\mathrm{F}_{1}=4 \\
\mathrm{~F}_{2}=8\end{array}$ \\
\hline $\begin{array}{l}\text { P-value } \\
\text { (Replication) } \\
\end{array}$ & $\begin{array}{c}\mathrm{P}>0.01 \& \\
\mathrm{P}<0.05\end{array}$ & $\mathrm{P}>0.01>0.05$ & $\mathrm{P}<0.01<0.05$ & $\mathrm{P}>0.01>0.05$ & $\begin{array}{c}\mathrm{P}>0.01 \& \\
\mathrm{P}<0.05\end{array}$ & $\mathrm{P}>0.01>0.05$ \\
\hline $\mathrm{LC}_{50}(\mathrm{ppm})$ & $8.609 \times 10^{-3}$ & $4.440 \times 10^{-4}$ & $9.094 \times 10^{-4}$ & $24.215 \times 10^{-5}$ & $4797 \times 10^{-4}$ & $7.022 \times 10^{-4}$ \\
\hline $\begin{array}{l}\begin{array}{l}\text { Confidence limit } \\
\text { (lower) }\end{array} \\
\end{array}$ & $6.425 \times 10^{-3}$ & $3.388 \times 10^{-4}$ & $6.651 \times 10^{-4}$ & $18.156 \times 10^{-5}$ & $3.598 \times 10^{-4}$ & $5.788 \times 10^{-4}$ \\
\hline $\begin{array}{l}\text { Confidence limit } \\
\text { (upper) }\end{array}$ & $11.342 \times 10^{-3}$ & $5.771 \times 10^{-4}$ & $12.240 \times 10^{-4}$ & $32.355 \times 10^{-5}$ & $6.360 \times 10^{-4}$ & $8.514 \times 10^{-4}$ \\
\hline $\mathrm{LC}_{90}(\mathrm{ppm})$ & $38.450 \times 10^{-3}$ & $17.594 \times 10^{-4}$ & $46.855 \times 10^{-4}$ & $113.536 \times 10^{-5}$ & $22.146 \times 10^{-4}$ & $19.486 \times 10^{-4}$ \\
\hline $\begin{array}{l}\text { Confidence limit } \\
\text { (lower) }\end{array}$ & $25.936 \times 10^{-3}$ & $12.168 \times 10^{-4}$ & $30.187 \times 10^{-4}$ & $74.239 \times 10^{-5}$ & $14.573 \times 10^{-4}$ & $14.620 \times 10^{-4}$ \\
\hline $\begin{array}{l}\begin{array}{l}\text { Confidence limit } \\
\text { (upper) }\end{array} \\
\end{array}$ & $72.840 \times 10^{-3}$ & $31.755 \times 10^{-4}$ & $98.103 \times 10^{-4}$ & $228.587 \times 10^{-5}$ & ${ }^{5} 44.694 \times 10^{-4}$ & $31.858 \times 10^{-4}$ \\
\hline
\end{tabular}


(Sithion) 57 EC, Delathroit (Dimethoate) 40 EC, Parathrin (Cypermethrin) 10 EC and Clorasid (Chloropyrics) 20 EC insecticides were bioassayed upon C. quinquefasciatus larvae at various concentrations. Records in terms of mortality were taken at an interval of 24 hours of exposure to the test insecticides. No control mortality was seen to occur. The values of the dose ranges and mortality ranges, slope line values, Chi square and ANOVA values, $\mathrm{LC}_{50}$ and $\mathrm{LC}_{90}$ values with their confidence limits of the six insecticides are given in Table 1. Probit mortality lines of the six insecticides for the species are shown in Fig 1.

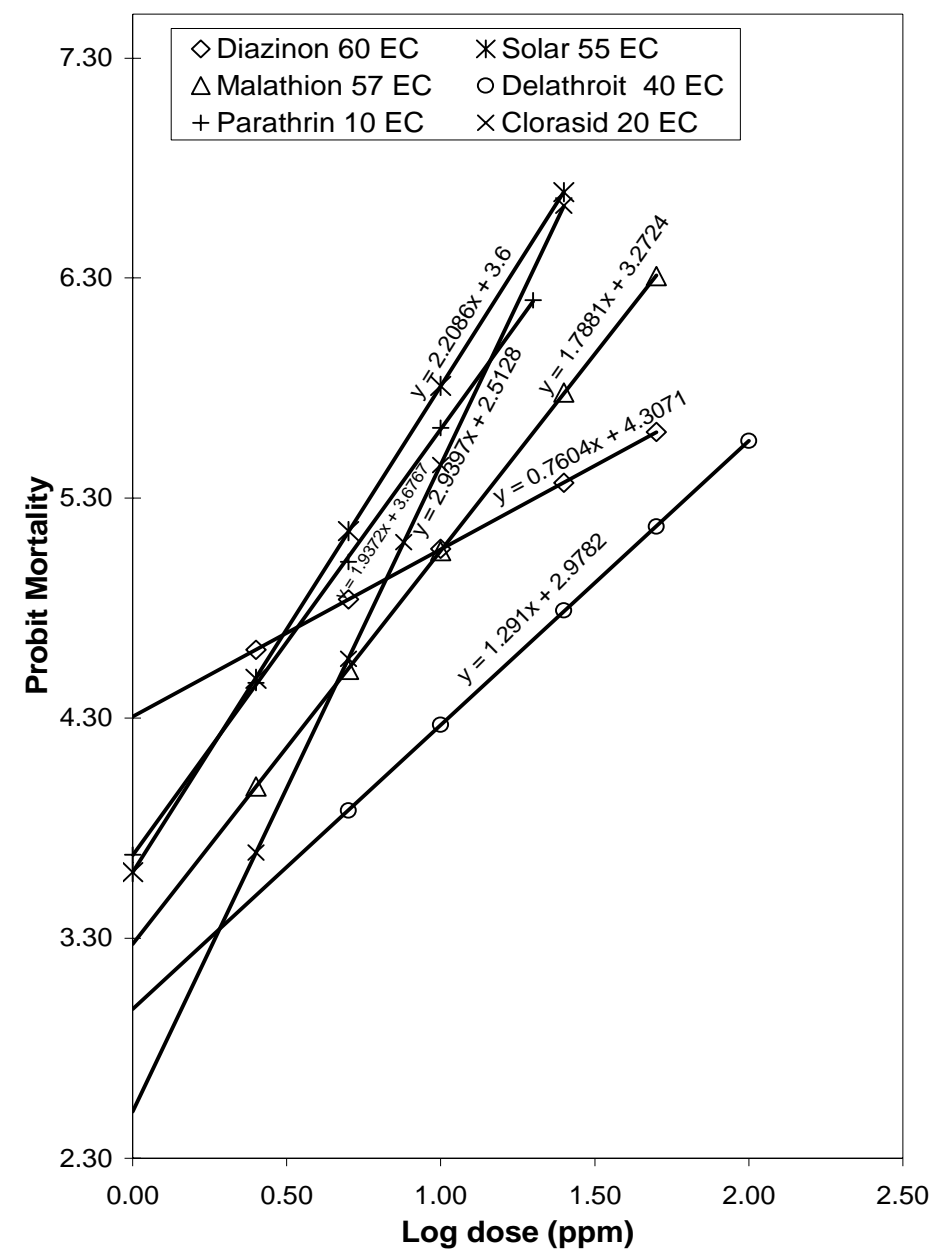

Fig 1. Regression lines for determining the $\mathrm{LC}_{50}$ of Diazinon 60 EC, Solar 55 EC, Malathion 57 EC, Delathroit 40 EC, Parathrin 10 EC and Clorasid 20 EC insecticides on Culex quinquefasciatus larvae after 24 hours of exposure. 
Relative potency values of the six insecticides: The relative potency values of the six insecticides on C. quinquefasciatus larvae were calculated and are presented in Table 2.

Table 2. The $\mathrm{LC}_{50}$ and relative potency values of Diazinon 60 EC, Solar 55 EC, Malathion 57 EC, Delathroit 40 EC, Parathrin 10 EC and Clorasid 20 EC on C. quinquefasciatus larvae.

\begin{tabular}{l|l|l|c}
\hline Insecticides & Extract & $\mathrm{LC}_{50}(\mathrm{ppm})$ & $\begin{array}{l}\text { Relative } \\
\text { Potency }\end{array}$ \\
& & & \\
\hline Diazinon 60 EC & Distilled water & $8.6087 \times 10^{-3}=86.087 \times 10^{-4}$ & 1.000 \\
Solar 55 EC & Distilled water & $4.440 \times 10^{-4}$ & 19.389 \\
Malathion 57 EC & Distilled water & $9.097 \times 10^{-4}$ & 9.463 \\
Delathroit 40 EC & Distilled water & $24.215 \times 10^{-5}$ & 35.544 \\
& & $=2.422 \times 10^{-4}$ & \\
Parathrin 10 EC & Distilled water & $4.797 \times 10^{-4}$ & 17.946 \\
Clorasid 20 EC & Distilled water & $7.022 \times 10^{-4}$ & 12.259 \\
\hline
\end{tabular}

From the Table 2 it is evident that amongst the six insecticides Delathroit 40 EC was the most toxic insecticide having low $\mathrm{LC}_{50}$ value $\left(2.422 \times 10^{-4} \mathrm{ppm}\right)$ and high relative potency value (35.544). The lowest toxic insecticide was Diazinon $60 \mathrm{EC}$ having a high $\mathrm{LC}_{50}$ value $\left(86.087 \times 10^{-4} \mathrm{ppm}\right)$ and low relative potency value (1.000). Hence, from the relative potency values it is suggested that Delathroit 40 EC was 35 times more toxic than Diazinon 60 EC extract. The relative position of the six insecticides on the basis of their $\mathrm{LC}_{50}$ and relative potency values was in the order: Delathroit $40 \mathrm{EC}>$ Solar $55 \mathrm{EC}>$ Parathrin 10 EC > Clorasid 20 EC > Malathion 57 EC > Diazinon 60 EC. From the results it may be concluded that of the six tested insecticides Delathroit was the most toxic, followed by Solar, Parathrin, Clorasid, Malathion and Diazinon. A comparison of the relative potency values amongst the six insecticides is shown in Table 3.

The effects of the six insecticides (Diazinon 60 EC, Solar 55 EC, Malathion 57 EC, Delathroit 40 EC, Parathrin 10 EC and Clorasid 20 EC) were studied in a dose dependent manner. In the present study, analysis of the data showed that Delathroit 40 EC was most toxic at $0.001 \mathrm{ppm}$, whereas $0.00005 \mathrm{ppm}$ was found to be the least toxic dose. Diazinon 60 EC, Solar 55 EC, Malathion 57 EC, Parathrin 10 EC and Clorasid 20 EC insecticides were highly toxic at $0.5 \mathrm{ppm}, 0.0025 \mathrm{ppm}, 0.005 \mathrm{ppm}, 0.002 \mathrm{ppm}$ and $0.0025 \mathrm{ppm}$ respectively whereas $0.0025 \mathrm{ppm}, 0.0001 \mathrm{ppm}, 0.00025 \mathrm{ppm}, 0.0001 \mathrm{ppm}$ and 0.00025 ppm were found to be the least toxic doses respectively.

From the mortality data it was also observed that the mortality of the experimental mosquito larvae increased with the gradual increase of the dose concentrations of different insecticides. Different mortality within the concentrations used, ranged between 10 and 97 percent. The order of larvicidal activity or toxicity of the six insecticides on $C$. quinquefasciatus observed in the present study was: Delathroit $40 \mathrm{EC}>$ Solar $55 \mathrm{EC}>$ Parathrin 10 EC > Clorasid 20 EC > Malathion 57 EC > Diazinon 60 EC. 
Table 3. Comparison of the relative potency values among the six insecticides.

\begin{tabular}{lc}
\hline Comparison between the insecticides & Relative potency \\
\hline Diazinon 60 EC relative to Solar 55 EC & 19.389 \\
Diazinon 60 EC relative to Malathion 57 EC & 9.463 \\
Diazinon 60 EC relative to Delathroit 40 EC & 35.544 \\
Diazinon 60 EC relative to Parathrin 10 EC & 17.946 \\
Diazinon 60 EC relative to Clorasid 20 EC & 12.259 \\
& \\
Solar 55 EC relative to Malathion 57 EC & 0.488 \\
Solar 55 EC relative to Delathroit 40 EC & 1.833 \\
Solar 55 EC relative to Parathrin 10 EC & 0.926 \\
Solar 55 EC relative to Clorasid 20 EC & 0.632 \\
& \\
Malathion 57 EC relative to Delathroit 40 EC & 3.756 \\
Malathion 57 EC relative to Parathrin 10 EC & 1.896 \\
Malathion 57 EC relative to Clorasid 20 EC & 1.295 \\
& \\
Delathroit 40 EC relative to Parathrin 10 EC & 0.505 \\
Delathroit 40 EC relative to Clorasid 20 EC & 0.345 \\
Parathrin 10 EC relative to Clorasid 20 EC & \\
\hline
\end{tabular}

The $\mathrm{LC}_{50}$ values and relative potency of the insecticides to the larvae as observed in the present investigation revealed that Delathroit $40 \mathrm{EC}$ was the most toxic to the test larvae and was about thirty five times more toxic than Diazinon 60 EC. Solar 55 EC and Parathrin 10 EC also showed more or less same relative potency and were two times less potent than Delathroit 40 EC. Malathion 57 EC and Clorasid 20 EC showed more or less similar relative potency and were 3-4 times less potent then Delathroit 40 EC. The $\mathrm{LC}_{50}$ values were found to be $2.424 \times 10^{-4}, 4.440 \times 10^{-4}, 4.797 \times 10^{-4}, 7.022 \times 10^{-4}, 9.097 \times 10^{-4}$ and $86.087 \times 10^{-4} \mathrm{ppm}$ for Delathroit 40 EC, Solar 55 EC, Parathrin 10 EC, Clorasid 20 EC, Malathion 57 EC and Diazinon 60 EC respectively. The relative potency of the insecticides to larvae of $C$. quinquefasciatus in order of decreasing toxicity was as follows: Delathroit 40 EC > Solar 55 EC > Parathrin 10 EC > Clorasid 20 EC > Malathion 57 EC > Diazinon 60 EC. Pal and Karla (1958) and Ramkrishnan et al. (1960) respectively observed $\mathrm{LD}_{50}$ values of Malathion as $0.032 \mathrm{ppm}$ and $0.031 \mathrm{ppm}$ on Culex sp. larvae. In the present test $\mathrm{LC}_{50}$ values of Malathion, $9.097 \times 10^{-4} \mathrm{ppm}$ indicated that the larvae of $C$. quinquefasciatus strain in Bangladesh is very susceptible than those tested by Pal and Karla (1958) and Ramkrishnan et al. (1960).

The dose ranges in the present findings were 0.0025-0.05 ppm for Diazinon 60 EC, 0.0001-0.0025 ppm for Solar 55 EC, 0.00025-0.005 ppm for Malathion 57 EC, 0.000050.001 ppm for Delathroit 40 EC, 0.0001-0.002 ppm for Parathrin 10 EC and 0.000250.0025 ppm for Clorasid 20 EC which were somewhat similar to the dose ranges found by Hossain et al. (1995) in case of Cypermethrin 10 EC (0.00006-0.00390 ppm), and Deltamethrin 2.5 EC (0.00006-0.00195 ppm) and Begum and Mirdha (1975) in case of Gusathion 20 EC (0.001-0.0001 ppm), Sumithion 50 EC (0.0002-0.0009 ppm), Lebaycid 
50 EC (0.0004-0.0007 ppm), Folithion 50 EC (0.0007-0.0014 ppm) and Birlane 50 EC $(0.002-0.010 \mathrm{ppm})$. The mortality range of the present observation was $10-97 \%$ which was more or less similar to the findings of Hossain et al. (1995) and Kumar et al. (2011) on Culex quinquefasciatus larvae, whereby mortality ranged from 0-100\% with Cypermethrin 10 EC and Deltamethrin 2.5 EC and 8-100\% with Propoxur and Bocide (Spinosad) respectively and Begum and Mirdha (1975) on Culex fatigans larvae whereby mortality ranged from 13-93\% with Gusathion 20 EC.

The range of the $\mathrm{LC}_{50}$ values of the present finding with $C$. quinquefasciatus was 0.0086 $\left(86.087 \times 10^{-4}\right) \mathrm{ppm}$ with Diazinon 60 EC to $0.00024\left(2.422 \times 10^{-4}\right) \mathrm{ppm}$ with Delathriot 40 EC which was similar to the findings of Sarar et al. (2011) with Temephos $\left(\mathrm{LC}_{50}=\right.$ $0.0079 \mathrm{mg} / \mathrm{L}$ or ppm), Kumar et al. (2011) with Propoxur $\left(\mathrm{LC}_{50}=0.00013 \mathrm{ppm}\right)$, Bansal and Singh (2006) with Alphamethrin ( $\mathrm{LC}_{50}=0.00021 \mathrm{mg} / \mathrm{L}$ or ppm), Kalyanasundaran et al. (2003) with Dursban (Chloropyrifos-ethyl) ( $\mathrm{LC}_{50}=0.00011 \mathrm{mg} / \mathrm{L}$ or $\left.\mathrm{ppm}\right)$, Hossain et al. (1995) with Cypermethrin $10 \mathrm{EC}\left(\mathrm{LC}_{50}=0.00034 \mathrm{ppm}\right)$ and with Deltamethrin 2.5 EC $\left(\mathrm{LC}_{50}=0.00029 \mathrm{ppm}\right)$, Begum and Mirdha (1975) with Gusathion 20 EC $\left(\mathrm{LC}_{50}=\right.$ $0.00033 \mathrm{ppm})$ and with Sumithion $50 \mathrm{EC}\left(\mathrm{LC}_{50}=0.00038 \mathrm{ppm}\right)$ on Culex quinquefasciatus and Culex fatigans larvae.

Results obtained from the present study clearly indicate that Diazinon 60 EC is least effective among the six insecticides tested. Under the consideration of above investigation, it is apparent that if we apply more insecticides at over dose, our environment will be polluted by these insecticides and the larvae will attain resistance.

\section{References}

Ali, A., M.A. Chowdhury, M.I. Hossain, M. Ameen, D.B. Habiba and A.F.M. Aslam. 1999. Laboratory evaluation of selected larvicides and insect growth regulators against fieldcollected Culex quinquefasciatus larvae from urban Dhaka, Bangladesh. J. Am. Mosq. Control Assoc. 15 (1): 43-47.

Bansal, S.K. and K.V. Singh. 2006. Laboratory evaluation for comparative insecticidal activity of some synthetic pyrethroids against vector mosquitoes in arid region. Journal of Environmental Biology 27: 251-255.

Begum, A . and M.M.B. Bhuiya. 1983. The susceptibility of Culex fatigans larvae to insecticides. Bangladesh J. Zool. 11 (1): 39-41.

Begum, A. and S.R. Mirdha. 1975. Toxicities of insecticides to larvae of Culex fatigans Wiedemann. Bangladesh J. Zool. 3 (2): 139-144.

Das P.K., T. Mariappan and C.B.S. Reddy. 1982. Susceptibility of Culex quinquefasciatus, Aedes aegypti and Anopheles culicifacies against insecticides. J. Med. Res. 75: 529-533.

Finney, D.J. 1971. Probit analysis. $3^{\text {rd }}$ edition. Cambridge University Press, London. 333 pp.

Fisher, R.A. and F. Yates. 1963. Statistical tables for Biological, Agricultural and Medicinal Research. $6^{\text {th }}$ ed. Oliver and Boyd Ltd. Edinburgh. 47-50 pp.

Hossain, M I., M. Ameen and A.K.M.R. Ahmed. 1995. Efficacy of two pyrethroid insecticides against Culex quinquefasciatus Say larvae in Dhaka City. Bangladesh J. Zool. 23 (2): 187-192. 
Kalyanasundaran, M., P. Jambulingam, S.S. Sahu, P.S. Doss, D.D. Amalraj and P.K. Das. 2003. Efficacy of two organophosphorous insecticides, Reldan and Dursban against the larvae of Culex quinquefasciatus. The Indian Journal of Medical Research 117: 25-29.

Kumar, R., A.K. Sharma, A.K. Gupta and M.P. Kaushik. 2010. Larvicidal activity of novel organophosphorus compounds against the Culex quinquefasciatus. International Journal of Drug Design and Cover 1 (3): 189-194.

Kumar, T.S., R.S. Kavitha, C.N. Nag, G.K. Navya, B.S. Raghavendra and V.A.. Vijayan. 2011. Present susceptibility status of Culex quinquefasciatus Say to four insecticides at Mysore, India. Research in Zoology, Univ. of Mysore. 1 (1): 8-11.

Michaelakis, A. and G. Koliopoulos. 2007. Attract and kill strategy. Laboratory studies on hatched larvae of Culex pipiens. Journal of Medical Entomology 63 (10): 954-959.

Miyagi, I., T. Toma, N. Zayasu and Y. Takashita. 1994. Insecticide susceptibility of Culex quinquefasciatus larvae (Diptera: Culicidae) in Okinawa prefecture, Japan in 1989. Japaneese. J. San. Zool. 45 (1): 7-11.

Nkya, T.E., F.W. Mosha, S.M. Magesaa and W.N. Kisinza. 2014. Increased tolerance of Anopheles gambiae S.S. to chemical insecticides after exposure to agrochemical mixture. Tanzania Journal of Health Research. 16 (4): 1-6.

Pal, R. and R.L. Karla. 1958. Comparative susceptibility of DDT resistant and normal Culex quinquefasciatus larvae to diphenyl methane derivatives and chlorinated insecticides. Indian J. of Malariol. 11 (4): 439-446.

Ramkrishnan, S.P., M.I.D. Sharma and R.L. Karla. 1960. Laboratory and field studies on the effectiveness of organophosphorus insecticides in the control of Culex quinquefasciatus. Indian J. Malariology. 11: 545-565.

Saha, P. 2003. Effectiveness and residual action of five selected organophosphate larvicides against third instar larvae of Culex quinquefasciatus. M.Sc. Thesis, Dept. Zooogy., Jahangirnagar University. $84 \mathrm{pp}$.

Sarar, A.S., Y. Abobakr and H.I. Hussein. 2011. Laboratory and field evaluation of some chemical and biological larvicides against Culex spp. (Diptera: Culicidae) immature stages. International J. of Agriculture and Biology. 13 (1): 115-119.

Shahjahan, R.M. 1996. Effects of insecticides selection pressure on the larvae of Aedes aegypti (L.) (Diptera: Culicidae). Bangladesh J. Zool. 24 (2): 97-102.

Thavaselavam, D., A. Kumar and P. K. Sumodan 1993. Insecticide susceptibility status of Anopheles stephensi, Culex quinquefasciatus and Aedes aegypti in Punjab, Goa. Indian J. Malariology. 30 (2): 75-79.

Verma, B.L. and A.C. Rajvanshi. 1983. Larvicidal efficacy of two synthetic pyrethroids against mosquitoes. J. Com. Dis. 15 (3): 219-221.

Zannat, T. 2003. Susceptibility levels of larvae of Culex quinquefasciatus against commonly used insecticides in Dhaka city. M..Sc. Thesis, Dept. Zoology Jahangirnagar University. 161 pp. 